\title{
Mode of Action and Functional Significance of Estrogen-Inducing Dendritic Growth, Spinogenesis, and Synaptogenesis in the Developing Purkinje Cell
}

\author{
Katsunori Sasahara, ${ }^{1}$ Hanako Shikimi, ${ }^{1}$ Shogo Haraguchi, ${ }^{1,3}$ Hirotaka Sakamoto, ${ }^{1}$ Shin-ichiro Honda, ${ }^{2}$ \\ Nobuhiro Harada, ${ }^{2}$ and Kazuyoshi Tsutsui ${ }^{1,3}$ \\ ${ }^{1}$ Laboratory of Brain Science, Faculty of Integrated Arts and Sciences, Hiroshima University, Higashi-Hiroshima 739-8521, Japan, ${ }^{2}$ Department of \\ Biochemistry, School of Medicine, Fujita Health University, Aichi 470-1192, Japan, and ${ }^{3}$ Laboratory of Integrative Brain Sciences, Department of Biology, \\ Faculty of Education and Integrated Arts and Sciences, Waseda University, Shinjuku-ku, Tokyo 169-8050, Japan
}

Neurosteroids are synthesized de novo from cholesterol in the brain. To understand neurosteroid action in the brain, data on the regioand temporal-specific synthesis of neurosteroids are needed. Recently, we identified the Purkinje cell as an active neurosteroidogenic cell. In rodents, this neuron actively produces several neurosteroids including estradiol during neonatal life, when cerebellar neuronal circuit formation occurs. Estradiol may be involved in cerebellar neuronal circuit formation through promoting neuronal growth and neuronal synaptic contact, because the Purkinje cell expresses estrogen receptor- $\beta(\operatorname{ER} \beta)$. To test this hypothesis, in this study we examined the effects of estradiol on dendritic growth, spinogenesis, and synaptogenesis in the Purkinje cell using neonatal wild-type (WT) mice or cytochrome P450 aromatase knock-out (ArKO) mice. Administration of estradiol to neonatal WT or ArKO mice increased dendritic growth, spinogenesis, and synaptogenesis in the Purkinje cell. In contrast, WT mice treated with tamoxifen, an ER antagonist, or ArKO mice exhibited decreased Purkinje dendritic growth, spinogenesis, and synaptogenesis at the same neonatal period. To elucidate the mode of action of estradiol, we further examined the expression of brain-derived neurotrophic factor (BDNF) in response to estrogen actions in the neonate. Estrogen administration to neonatal WT or ArKO mice increased the BDNF level in the cerebellum, whereas tamoxifen decreased the BDNF level in WT mice similar to ArKO mice. BDNF administration to tamoxifen-treated WT mice increased Purkinje dendritic growth. These results indicate that estradiol induces dendritic growth, spinogenesis, and synaptogenesis in the developing Purkinje cell via BDNF action during neonatal life.

Key words: Purkinje cell; neurosteroids; estradiol; cytochrome P450 aromatase; brain-derived neurotrophic factor; dendritic outgrowth; spine formation; synapse formation; cerebellar neuronal circuit formation; development; knock-out mice

\section{Introduction}

Neurosteroids are synthesized de novo from cholesterol in the CNS and PNS of vertebrates (for review, see Baulieu, 1997; Compagnone and Mellon, 2000; Tsutsui et al., 2000). To analyze neurosteroid action in the brain, data on the regio- and temporalspecific synthesis of neurosteroids are needed. We demonstrated recently that the Purkinje cell, a cerebellar neuron, is a major site for neurosteroid formation in various vertebrates including rodents (for review, see Tsutsui et al., 2000, 2003a,b; Tsutsui and Mellon, 2006). The rat Purkinje cell possesses several kinds of steroidogenic enzymes, such as cytochrome P450 side-chain cleavage enzyme and $3 \beta$-hydroxysteroid dehydrogenase $/ \Delta^{5}-\Delta^{4}$ isomerase ( $3 \beta$-HSD), and actively produces progesterone de novo

\footnotetext{
Received Feb. 16, 2007; revised May 30, 2007; accepted June 2, 2007.

This work was supported in part by Ministry of Education, Science, and Culture, of Japan Grants-in-Aid for Scientific Research 15207007, 16086206, and 18107002 (K.T.).

Correspondence should be addressed to Kazuyoshi Tsutsui, Laboratory of Integrative Brain Sciences, Department of Biology, Faculty of Education and Integrated Arts and Sciences, Waseda University, 1-6-1 Nishi-Waseda, Shinjukuku, Tokyo 169-8050, Japan. E-mail: k-tsutsui@waseda.jp.

DOI:10.1523/JNEUROSCI.0710-07.2007

Copyright $\odot 2007$ Society for Neuroscience $\quad 0270-6474 / 07 / 277408-10 \$ 15.00 / 0$
}

from cholesterol as a product of an increase of $3 \beta$-HSD activity during neonatal life (Ukena et al., 1998, 1999; Tsutsui et al., 2003a,b). More recently, we further demonstrated that the rat Purkinje cell expresses a key enzyme of estrogen formation, cytochrome $\mathrm{P} 450$ aromatase (P450arom) and produces estradiol during neonatal life (Sakamoto et al., 2003a).

Because the Purkinje cell produces several kinds of neurosteroids at particular times, this neuron is considered to serve as an excellent cellular model for the study of neurosteroid actions. It is well known that, in the rat, marked morphological changes occur in the cerebellum after birth during neonatal life (Altman, 1972a,b). Rat Purkinje cells differentiate just after birth, and the formation of the cerebellar neuronal circuit becomes complete in the neonate, when the formation of progesterone and estradiol are high (Ukena et al., 1999; Sakamoto et al., 2003a). Therefore, progesterone and estradiol synthesized in the developing Purkinje cell may be important factors for cerebellar neuronal circuit formation during neonatal life. In fact, we have shown that progesterone promotes dendritic growth, spinogenesis, and synaptogenesis via intranuclear receptor for progesterone in the Purkinje cell during rat neonatal life (Sakamoto et al., 2001a, 2002, 
Table 1. Morphological comparisons of Purkinje dendrites, dendritic spines, and dendritic synapses between male and female newborn WT mice

\begin{tabular}{|c|c|c|c|c|c|c|}
\hline Group & $\begin{array}{l}\text { Number of } \\
\text { mice }\end{array}$ & $\begin{array}{l}\text { Maximal dendritic } \\
\text { length }(\mu \mathrm{m})\end{array}$ & $\begin{array}{l}\text { Number of cells } \\
\text { per mm lobe IX }\end{array}$ & $\begin{array}{l}\text { Number of spines } \\
\text { per } 100 \mu \mathrm{m}^{2}\end{array}$ & $\begin{array}{l}\text { Number of spine } \\
\text { synapses per } \mu \mathrm{m}^{3}\end{array}$ & $\begin{array}{l}\text { Number of shaft } \\
\text { synapses per } \mu \mathrm{m}^{3}\end{array}$ \\
\hline Male & 5 & $37.8 \pm 1.6$ & $38.3 \pm 1.7$ & $49.4 \pm 1.8$ & $0.331 \pm 0.005$ & $0.051 \pm 0.002$ \\
\hline Female & 5 & $38.4 \pm 2.2$ & $39.5 \pm 1.5$ & $53.1 \pm 5.4$ & $0.363 \pm 0.028$ & $0.050 \pm 0.008$ \\
\hline
\end{tabular}

There were no sex differences in these morphological parameters between male and female newborn mice.

2003b). Estradiol may also contribute to these events, because estradiol promotes dendritic growth of Purkinje cells (Sakamoto et al., 2003a), which express estrogen receptor- $\beta$ (ER $\beta)$ in the rat neonate (Price and Handa, 2000; Jakab et al., 2001).

To demonstrate the functional significance of estradiol in the developing Purkinje cell, this study investigated estrogen actions on dendritic growth, spinogenesis, and synaptogenesis in the Purkinje cell using neonatal wild-type (WT) mice or cytochrome P450arom knock-out (ArKO) mice. ArKO mice used in this study lack exons 1 and 2 and the proximal promoter region of the P450arom gene cyp19 (cytochrome P450, family 19) (Honda et al., 1998). To elucidate the mode of action of estradiol, we further examined the expression of neurotrophic factors, such as brainderived neurotrophic factor (BDNF) and neurotrophin-3 (NT-3) in the neonatal cerebellum, because BDNF and NT-3 are known to be critical for proper development of Purkinje cells (Rocamora et al., 1993; Ernfors et al., 1994; Neveu and Arenas, 1996; Schwartz et al., 1997; Bates et al., 1999). Here we show that estradiol induces Purkinje dendritic growth, spinogenesis, and synaptogenesis via BDNF action during neonatal development.

\section{Materials and Methods}

Animals. Male and female mice of the C57BL/6 strain maintained in this laboratory were mated and housed in a temperature-controlled room $\left(25 \pm 2^{\circ} \mathrm{C}\right)$ under a daily photoperiod of $14 / 10 \mathrm{~h}$ light/dark cycle (lights on at 6:00 A.M.). Newborn WT or ArKO mice were used to investigate the effects of estradiol on dendritic growth, spinogenesis, and synaptogenesis in the Purkinje cell. To elucidate the mode of action of estradiol, the expression of neurotrophic factors, such as BDNF and NT-3, in the cerebellum was analyzed using newborn WT or ArKO mice.

ArKO mice were prepared by pairing heterozygous mutant animals that were generated by targeted disruption of the P450arom gene cyp19 (Honda et al., 1998; Bakker et al., 2002a,b; Matsumoto et al., 2003). ArKO and WT mice were also housed in a temperature-controlled room $\left(25 \pm 2^{\circ} \mathrm{C}\right)$ under a daily photoperiod of $14 / 10 \mathrm{~h}$ light/dark cycle (lights on at 6:00 A.M.). The offspring was genotyped by PCR analysis of cerebral genomic DNA with primer pairs as follows: an antisense primer [Arom reverse (R) primer, $5^{\prime}$-TTACCATGTCCTAATCTTCAC-3'] and a sense primer [Arom forward (F) primer, 5'-CTTGTCTAAGTGTCCAATCAC-3'] for the intrinsic mouse P450arom gene cyp19 (a $504 \mathrm{bp}$ product) and an antisense primer (Neo primer, 5' TAAAGCGCATGCTCCAGACT- $3^{\prime}$ ) and a sense AromF primer for the P450arom gene disrupted by insertion of a neomycin-resistant gene (a 180 bp product). The WT allele of the $\mathrm{P} 450$ arom gene cyp 19 was amplified by PCR using the AromF primer and the AromR primer, whereas the mutated allele was amplified by PCR using the Neo primer and the AromR primer. PCR was performed for 30 cycles $\left(94^{\circ} \mathrm{C}, 40 \mathrm{~s} ; 58^{\circ} \mathrm{C}, 40 \mathrm{~s}\right.$; $72^{\circ} \mathrm{C}, 30 \mathrm{~s}$ ) with $40-50 \mathrm{ng}$ of genomic DNA. PCR products were separated on 1.5\% NuSieve 3:1 agarose (TaKaRa, Kyoto, Japan).

The experimental protocol was approved in accordance with the Guide for the Care and Use of Laboratory Animals prepared by the committee of the Hiroshima University (Higashi-Hiroshima, Japan). All efforts were made to minimize the number of animals used and their suffering.

In vivo estrogen treatment. To investigate the estrogen effects on morphological changes of Purkinje cells in vivo, we used estradiol benzoate (EB) (Sigma, St. Louis, MO), which is more stable than estradiol-17 $\beta$. In our previous study with newborn rats (Sakamoto et al., 2003a), EB promoted dose-dependent dendritic growth of Purkinje cells, and a significant increase in Purkinje dendrites was induced by EB at $5 \mu \mathrm{g} / \mathrm{d}$ in vivo in rats. According to Sakamoto et al. (2003a), Purkinje cell is considered to be a major site of estrogen formation in the cerebellum during neonatal development. This study therefore focused on the action of estradiol produced locally in Purkinje cells, and the treatments were performed by injections close to the site of the neuroanatomical analysis. $\mathrm{EB}(2 \mu \mathrm{g} / 10 \mu \mathrm{l})$ dissolved in sesame oil was injected into the CSF around the posterior vermal lobe (IX) of the cerebellum of newborn WT mice once per day, for $3 \mathrm{~d}$, during 3-5 $\mathrm{d}$ of age. Pups receiving injections of the vehicle alone (sesame oil) served as controls. In this study, tamoxifen (Sigma), an ER antagonist, was also injected into pups once per day, for $3 \mathrm{~d}$, during 3-5 d of age. Tamoxifen dissolved in sesame oil $(200 \mu \mathrm{g} / 10 \mu \mathrm{l})$ or EB $(2 \mu \mathrm{g} / 10 \mu \mathrm{l})$ plus tamoxifen $(200 \mu \mathrm{g} / 10 \mu \mathrm{l})$ dissolved in sesame oil was injected as described above. After decapitation under deep anesthesia, cerebella of vehicle-, EB-, tamoxifen-, and EB plus tamoxifentreated pups at $6 \mathrm{~d}$ of age were dissected out.

To demonstrate the action of endogenous estrogen, newborn ArKO mice at $6 \mathrm{~d}$ of age were further used. ArKO mice received daily injections of EB at $2 \mu \mathrm{g} / \mathrm{d}$ (EB-treated ArKO mice) during 3-5 d of age as described above. WT pups receiving injections of the vehicle alone (sesame oil) served as controls. After decapitation under deep anesthesia, cerebella of WT, ArKO, and EB-treated ArKO pups were dissected out.

Section preparation and cellular labeling of Purkinje cells with calbindin. At $6 \mathrm{~d}$ of age, pups were deeply anesthetized with chloroform before transcardial perfusion with PBS [10 mM phosphate buffer (PB) and 140 $\mathrm{mm} \mathrm{NaCl}, \mathrm{pH} 7.3$ ], followed by fixative solution [2\% paraformaldehyde, $2.5 \%$ glutaraldehyde, and $15 \%$ saturated picric acid $(\mathrm{v} / \mathrm{v})$ in phosphate buffer]. Vermal cerebella were dissected out and sectioned parasagittally at $50 \mu \mathrm{m}$ thickness with a microslicer before immunostaining with the antibody against calbindin, a marker protein of the Purkinje cell.

Purkinje cells were identified by immunostaining with a mouse monoclonal antibody raised against calbindin- $\mathrm{D}_{28 \mathrm{k}}$ (Swant, Bellinzona, Switzerland), according to our previous method (Sakamoto et al., 2001a, 2002, 2003a,b). Cerebellar sections were prepared as described above and processed for immunocytochemistry. After elimination of endogenous peroxidase activity with $3 \% \mathrm{H}_{2} \mathrm{O}_{2}$ ( $0 \%$ for electron microscopic study) and blocking nonspecific binding components with $1 \%$ normal horse serum and $1 \% \mathrm{BSA}$, the sections were immersed overnight at $4^{\circ} \mathrm{C}$ with the monoclonal antibody against calbindin at a dilution of 1:50,000. Immunoreactive products were detected with an avidin-biotin kit (Vectastain Elite kit; Vector Laboratories, Burlingame, CA), followed by diaminobenzidine reaction, as described previously (Ukena et al., 1998; Sakamoto et al., 2001a, 2002, 2003a,b).

Light microscopic analysis of the morphology of Purkinje cells. WT pups injected with vehicle, EB, tamoxifen, and EB plus tamoxifen $(n=10$ in each group) and pups of WT, ArKO, and EB-treated ArKO $(n=5$ in each group) at $6 \mathrm{~d}$ of age were used for light microscopic analyses of the morphology of Purkinje cells, according to our previous method (Sakamoto et al., 2001a, 2002, 2003a). In brief, the length of molecular layer in the parasagittal section was evaluated as a parameter of the maximal Purkinje dendritic length [see Fig. 1A, M (molecular layer)], because Purkinje cell dendrites at $6 \mathrm{~d}$ of age were developed and were not clearly distinguishable from neighboring immunoreactive cells (Sakamoto et al., 2001a, 2002, 2003a). It is well known that the planar Purkinje cell dendrites are aligned in the cerebellum in the parasagittal plane (Altman, 1972b). At least 15 regions from four calbindin-immunostained sections per animal were randomly selected in the vermal lobe IX around the site of in vivo injection. The maximal dendritic length was measured using an ocular micrometer. Because there were no sex differences in the maximal Purkinje dendritic length and the numbers of Purkinje dendritic spines and axospinous synapses in WT mice at $6 \mathrm{~d}$ of age (Table 1), the data obtained from male and female pups were analyzed together.

For morphological analysis of the number of Purkinje cells, at least 
nine regions from four calbindin-immunostained sections per animal were randomly selected in the vermal lobe IX around the site of in vivo injection. The number of Purkinje cells was counted and expressed per $1 \mathrm{~mm}$.

Electron microscopic analysis of the morphology of Purkinje cells. For electron microscopy, calbindin immunocytochemically stained lobe sections of vehicle-, EB-, tamoxifen-, and EB plus tamoxifen-treated WT pups $(n=5$ in each group) at $6 \mathrm{~d}$ of age were postfixed in $1 \%$ osmium tetroxide in $\mathrm{PB}$, dehydrated in ascending grades of ethanol, and then embedded flat in epoxy resin (Quetol-812; Nisshin EM, Tokyo, Japan) according to our previous method (Sakamoto et al., 2000, 2001a). Pups of WT, ArKO, and EB-treated ArKO $(n=5$ in each group) at $6 \mathrm{~d}$ of age were also postfixed, dehydrated, and embedded. Ultrathin sections (60 $\mathrm{nm}$ in thickness) containing calbindinimmunoreactive Purkinje dendrites in lobe IX were collected in slot grids coated with Formvar film, electron stained with uranyl acetate and lead citrate, and viewed under an $\mathrm{H}-600 \mathrm{~A}$ electron microscope (Hitachi, Tokyo, Japan). All electron microphotographs were coded and evaluated without knowledge of the experimental group, and the code was not broken until the analysis was complete. At least 25 electron microphotographs (photographed at $6000 \times$ and printed at $15,000 \times$ magnification) of random regions in the superficial molecular layer of lobe IX were generated from five different animals per each experimental group. The number of asymmetrical synapses, defined as having both a postsynaptic density and at least three synaptic vesicles in the presynaptic terminal no more than $0.2 \mu \mathrm{m}$ from the synaptic cleft, was counted. The asymmetrical synapses on Purkinje dendritic spines were counted separately from those on dendritic shafts. Because relatively few cross sections contained a spine neck or spine apparatus, spines were defined as postsynaptic processes smaller than $2 \mu \mathrm{m}$ in diameter, lacking mitochondria (Woolley and McEwen, 1992; Bravin et al., 1999). The length of each synaptic membrane was measured using an NIH Image software package from electron micrographs. The density of synapses per volume (estNsv) was calculated using an unfolding stereological method of Cruz-Orive (1983), according to the formula est $N s v=Q s /(D s \times \pi / 4+t)$, where estNsv is the number of synapses per unit volume, $Q s$ is the number of synapses per unit area, $D s$ is the mean length of synaptic contact zones, and $t$ is the thickness of the ultrathin section (average thickness, $60 \mathrm{~nm}$ ) (Cruz-Orive, 1983).

Preparation of tissue samples and BDNF and NT-3 measurements. To elucidate the mode of action of estradiol, this study further measured the expression of BDNF and NT-3 in the cerebellum in response to estrogen actions. Brains of vehicle- $(n=8)$, EB- $(n=8)$, tamoxifen$(n=8)$, and EB plus tamoxifen- $(n=8)$ treated WT pups at $6 \mathrm{~d}$ of age were rapidly removed from their skulls. Cerebella were rapidly dissected out, weighed, and snap frozen on dry ice. Cerebella of WT $(n=8)$, ArKO $(n=8)$, and EB-treated ArKO $(n=8)$ pups were also dissected out. Cerebellar tissues were stored at $-80^{\circ} \mathrm{C}$ before homogenization. BDNF and NT-3 were extracted from cerebellar tissues by homogenization $(1: 10 \mathrm{w} / \mathrm{v}$ dilution) in $100 \mathrm{~mm}$ piperizine ethane sulfonic acid homogenization buffer, $\mathrm{pH} 7.0$, containing $500 \mathrm{~mm} \mathrm{NaCl}, 0.2 \% \mathrm{BSA}, 0.2 \%$ Triton $\mathrm{X}-100,0.1 \% \mathrm{NaN}_{3}$, and fresh protease inhibitors $(2 \mu \mathrm{g} / \mathrm{mg}$ aprotinin, 2 mM EDTA, $10 \mu \mathrm{m}$ leupeptin, $1 \mu \mathrm{M}$ pepstatin, and $200 \mu \mathrm{M}$ PMSF) using ground-glass Dounces (Pollock et al., 2001). Homogenates were centrifuged at $17,000 \times g$ for $10 \mathrm{~min}$, and supernatants were stored at $-80^{\circ} \mathrm{C}$ before ELISAs for BDNF and NT-3. BDNF and NT-3 protein levels were measured with standard two-antibody sandwich ELISAs (BDNF or NT-3

$\mathrm{E}_{\max }$ immunoassay system; Promega, Madison, WI). BDNF and NT-3 ELISAs were performed according to the protocol of the manufacturer.

In vivo BDNF treatment. To investigate the effect of BDNF on Purkinje cell morphology, local administration of recombinant human BDNF (Sigma) to tamoxifen-treated newborn WT mice was performed. According to Givalois et al. (2004), recombinant human BDNF (150 pg/10 $\mu \mathrm{l})$ was dissolved in sesame oil and injected. Tamoxifen dissolved in sesame oil $(200 \mu \mathrm{g} / 10 \mu \mathrm{l})$ or recombinant human BDNF $(150 \mathrm{pg} / 10 \mu \mathrm{l})$ plus tamoxifen $(200 \mu \mathrm{g} / 10 \mu \mathrm{l})$ dissolved in sesame oil was injected into CSF around the posterior vermal lobe (IX) of the cerebellum of newborn WT mice once per day, for $3 \mathrm{~d}$, during 3-5 d of age. Pups receiving injections of the vehicle alone (sesame oil) were also analyzed. After decapitation under deep anesthesia, cerebella of vehicle-, tamoxifen-, and BDNF plus tamoxifen-treated WT pups ( $n=10$ in each group) at $6 \mathrm{~d}$ of age were dissected out and used for light microscopic analyses of the morphology of Purkinje cells, as described above.

Statistical analyses. Statistical differences for morphological changes in Purkinje cells after in vivo treatment with $\mathrm{EB}$, tamoxifen, and $\mathrm{EB}$ plus tamoxifen were analyzed by one-way ANOVA. Morphological changes in Purkinje cells among WT, ArKO, and EB-treated ArKO mice were also analyzed by one-way ANOVA. If significant by these ANOVAs, the analyses were followed by Duncan's multiple range test (Bliss, 1952). Similarly, statistical differences for BDNF and NT-3 levels in cerebella among different groups and for morphological changes in Purkinje cells after in vivo treatment with BDNF were analyzed by one-way ANOVA, followed by Duncan's multiple range test (Bliss, 1952). Statistical analyses of these in vivo studies were based on the individual animal.

\section{Results}

Estrogen promotes dendritic growth, spinogenesis, and synaptogenesis in mouse Purkinje cells during development Morphological analysis revealed that estrogen administration induced the dendritic outgrowth of Purkinje cells (Figs. 1A-D, 2A). 


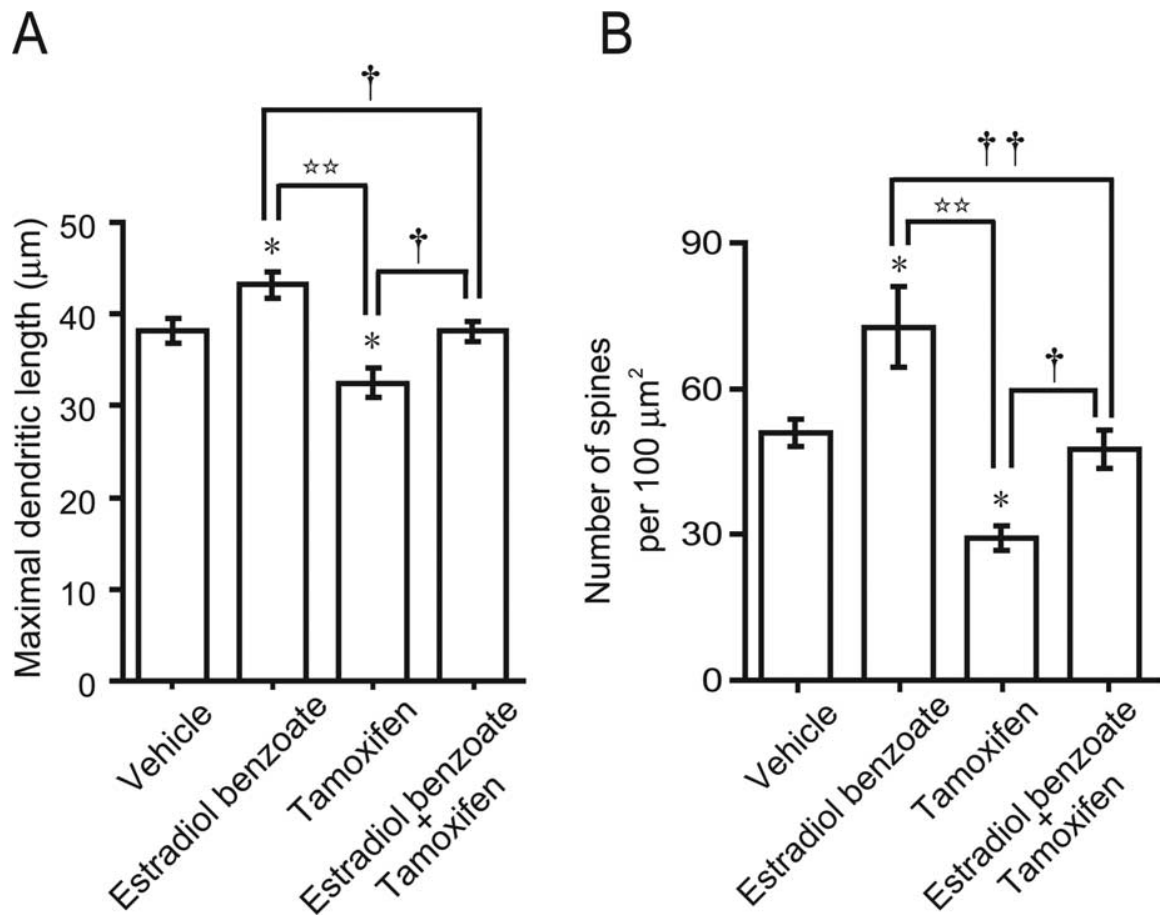

Figure 2. $A$, Quantitative analysis of the maximal Purkinje dendritic length of newborn WT mice treated with vehicle, $E B$ tamoxifen, or EB plus tamoxifen. Each column and error bar represent the mean $\pm \mathrm{SEM}$ ( $n=10$ in each group). ${ }^{*} p<0.05$ versus vehicle; ${ }^{\dagger} p<0.05$ EB or tamoxifen vs EB plus tamoxifen; ${ }^{2} p<0.01 \mathrm{~EB}$ vs tamoxifen (by one-way ANOVA, followed by Duncan's multiple range test). $B$, Quantitative electron microscopic analysis of Purkinje dendritic spine density per unit area (100 $\mu \mathrm{m}^{2}$ field) of newborn WT mice treated with vehicle, EB, tamoxifen, or EB plus tamoxifen. Each column and error bar represent the mean \pm SEM ( $n=5$ in each group). ${ }^{*} p<0.05$ versus vehicle; ${ }^{\dagger} p<0.05$ and ${ }^{\dagger+} p<0.01$ EB or tamoxifen versus EB plus tamoxifen; $p<$ 0.01 EB versus tamoxifen (by one-way ANOVA, followed by Duncan's multiple range test).

In the present study, the length of molecular layer was analyzed as a parameter of the maximal Purkinje dendritic length at $6 \mathrm{~d}$ of age after in vivo treatments with EB, tamoxifen, and EB plus tamoxifen ( $n=10$ in each group) after immunostaining for calbindin (Fig. $1 A-D, M)$. EB administration $(2 \mu \mathrm{g} / \mathrm{d})$ increased the maximal Purkinje dendritic length (Fig. $1 A, B$ ). Quantitative light microscopic analysis also revealed that treatment with EB alone $(2 \mu \mathrm{g} / \mathrm{d})$ induced a significant increase in the maximal Purkinje dendritic length ( $p<0.05$ vs vehicle-treated group) (Fig. $2 A$ ). We further investigated whether the stimulatory effect of EB on the maximal Purkinje dendritic length is blocked by tamoxifen, an antagonist of ER (both $\alpha$ and $\beta$ subtypes). Combined treatments with EB $(2 \mu \mathrm{g} / \mathrm{d})$ and tamoxifen at a concentration of 200 $\mu \mathrm{g} / \mathrm{d}$ (100 times greater than the EB concentration) revealed that tamoxifen abolished the estrogen-induced dendritic outgrowth of Purkinje cells ( $p<0.05$ vs EB-treated group) (Figs. $1 B, D, 2 A$ ). Treatment with tamoxifen alone $(200 \mu \mathrm{g} / \mathrm{d})$ also decreased significantly $(p<0.05)$ the maximal Purkinje dendritic length compared with the vehicle-treated group (Figs. $1 A, C, 2 A$ ), suggesting the action of endogenous estrogen on Purkinje dendritic length. In contrast, there was no significant difference in the number of Purkinje cells among the four groups (Table 2).

Morphological changes in dendritic spines of the calbindinlabeled Purkinje cell of newborn mice after in vivo treatment with EB for $3 \mathrm{~d}$ were analyzed ultrastructurally using an electron microscope (Fig. $1 E-H)$. Interestingly, EB administration $(2 \mu \mathrm{g} / \mathrm{d})$ increased the density of dendritic spines on Purkinje cells (Fig. $1 E, F)$. Quantitative electron microscopic analysis also revealed that the density of dendritic spines on Purkinje cells $\left(100 \mu \mathrm{m}^{2}\right.$ field) in the EB-treated group $(n=5)$ was significantly larger $(p<0.05)$ than that in the vehicle-treated group $(n=5)$ (Fig. $2 B$ ). We therefore investigated whether the stimulatory effect of EB on the density of Purkinje dendritic spines is blocked by tamoxifen. Combined treatments $(n=5)$ with $\mathrm{EB}(2 \mu \mathrm{g} / \mathrm{d})$ and tamoxifen $(200 \mu \mathrm{g} / \mathrm{d})$ revealed that tamoxifen abolished the estrogen-induced dendritic spine proliferation of Purkinje cells ( $p<0.01$ vs EB-treated group) (Figs. $1 F, H, 2 B)$. Treatment with tamoxifen alone $(200 \mu \mathrm{g} / \mathrm{d} ; n=5)$ also decreased significantly $(p<0.05)$ the density of Purkinje dendritic spines compared with the vehicle-treated group (Figs. $1 E, G, 2 B$ ), suggesting the action of endogenous estrogen on Purkinje dendritic spines.

Furthermore, quantitative electron microscopic analysis using an unfolding method revealed that the density of axospinous synapses (Fig. 3A) on Purkinje cells in the $\mathrm{EB}(2 \mu \mathrm{g} / \mathrm{d})$-treated group ( $n=$ $5)$ was significantly larger $(p<0.01)$ than that in the vehicle-treated group $(n=5)$ (Fig. 3C). Administration of EB $(2 \mu \mathrm{g} / \mathrm{d})$ was followed by a $45 \%$ increase in the density of synapses on Purkinje dendritic spines compared with the vehicle-treated group (Fig. 3C). Combined treatments ( $n$ $=5)$ with $\mathrm{EB}(2 \mu \mathrm{g} / \mathrm{d})$ and tamoxifen (200 $\mu \mathrm{g} / \mathrm{d})$ revealed that tamoxifen abolished the estrogen-induced synaptic formation of Purkinje cells $(p<0.01$ vs EB-treated group) (Fig. 3C). Quantitative electron microscopic analysis also revealed that the density of axospinous synapses on Purkinje cells in the tamoxifen $(200 \mu \mathrm{g} / \mathrm{d})$-treated group $(n=5)$ was significantly lower $(p<0.05)$ than that in the vehicle-treated group $(n=5)$ (Fig. $3 C$ ), suggesting the action of endogenous estrogen on synapses on Purkinje dendritic spines. In contrast to axospinous synapses, there was no significant difference in the density of synapses (Fig. 3B) located on Purkinje dendritic shafts after any treatment (Fig. 3D).

\section{Cytochrome P450arom gene deficiency inhibits dendritic growth, spinogenesis, and synaptogenesis in mouse Purkinje cells during development}

Although estrogen administration to newborn WT mice promoted dendritic outgrowth, spine proliferation, and synaptic formation of Purkinje cells in vivo, the actions of endogenous estrogen on these morphological changes are still unclear. Therefore, this experiment was designed to verify the actions of endogenous estrogen on Purkinje dendritic growth, spinogenesis, and synaptogenesis using ArKO mice in the neonate. The morphology of Purkinje cells was compared among the groups of WT, ArKO, and EB-treated ArKO mice ( $n=5$ in each group) at $6 \mathrm{~d}$ of age after immunostaining for calbindin (Fig. 4A-C). As shown in Figure $4, A$ and $B$, cytochrome P450arom gene deficiency decreased the dendritic outgrowth of Purkinje cells. We therefore evaluated the length of molecular layer as a parameter of the maximal Purkinje dendritic length (Fig. 4A-C, M). The maximal Purkinje dendritic length of ArKO mice was significantly lower than that of WT mice $(p<0.05)$ (Fig. $5 A)$. Administration of EB $(2 \mu \mathrm{g} / \mathrm{d})$ to ArKO mice significantly increased the maximal Pur- 
Table 2. Comparison of Purkinje cell number among vehicle-, EB-, tamoxifen-, and EB plus tamoxifen-treated newborn WT mice

\begin{tabular}{lll}
\hline Group & Number of mice & Number of cells per mm lobe IX \\
\hline Vehicle & 10 & $38.9 \pm 1.5$ \\
EB & 10 & $39.5 \pm 1.0$ \\
Tamoxifen & 10 & $39.5 \pm 1.5$ \\
EB + tamoxifen & 10 & $39.3 \pm 1.5$ \\
\hline
\end{tabular}

There was no significant difference in the Purkinje cell number among different treatments.
Spine
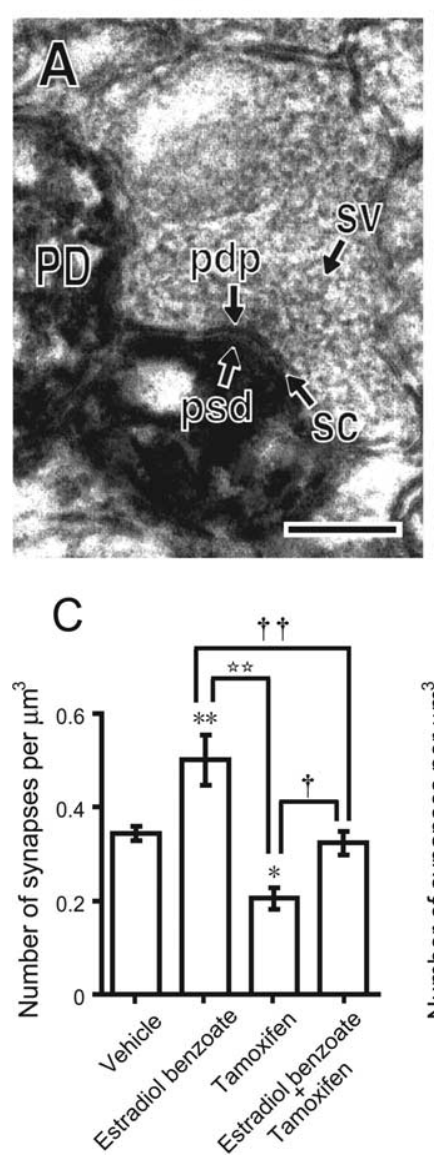

Shaft

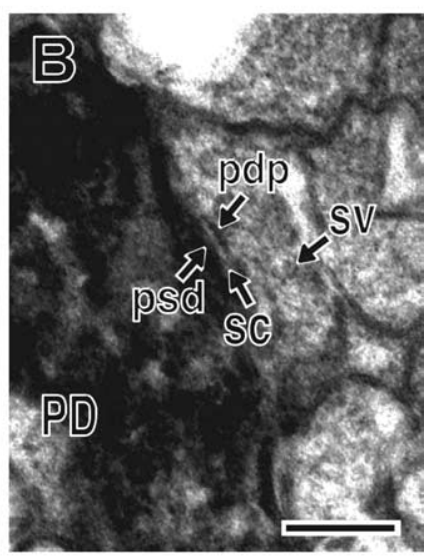

D

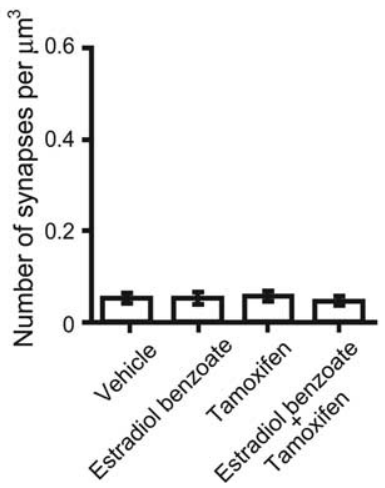

Figure 3. $\quad A, B$, Higher magnification of synaptic terminals in the molecular layers of vermal cerebella (lobe IX). Arrows indicate postsynaptic density (psd), synaptic vesicle (sv), synaptic cleft (sc), and presynaptic dense projections (pdp). PD, Purkinje cell dendrite. Scale bars, 500 nm. $C, D$, Quantitative electron microscopic analysis of Purkinje dendritic synapse density of newborn WT mice treated with vehicle, EB, tamoxifen, or EB plus tamoxifen. C, Axospinous synapse density. $\boldsymbol{D}$, Shaft synapse density. Ultrathin sections ( $60 \mathrm{~nm}$ in thickness) containing calbindin-immunoreactive Purkinje dendrites in lobe IX at $6 \mathrm{~d}$ of age were analyzed. Each column and error bar represent the mean \pm SEM ( $n=5$ in each group). ${ }^{*} p<0.05$ and ${ }^{* *} p<$ 0.01 versus vehicle; ${ }^{\dagger} p<0.05$ and ${ }^{+\dagger} p<0.01 \mathrm{~EB}$ or tamoxifen versus $\mathrm{EB}$ plus tamoxifen; $p<0.01 \mathrm{~EB}$ versus tamoxifen (by one-way ANOVA, followed by Duncan's multiple range test).

kinje dendritic length ( $p<0.05$ vs ArKO group), which reached the level of WT mice (Fig. 5A). In contrast to the Purkinje dendritic length, there was no significant difference in the Purkinje cell number among the groups of WT, ArKO, and EB-treated ArKO mice (Table 3).

Subsequently, morphological differences in dendritic spines of the calbindin-labeled Purkinje cell among WT, ArKO, and EB-treated ArKO mice were further analyzed ultrastructurally using an electron microscope (Fig. $4 D-F$ ). Interestingly, cytochrome P450arom gene deficiency decreased the density of den-
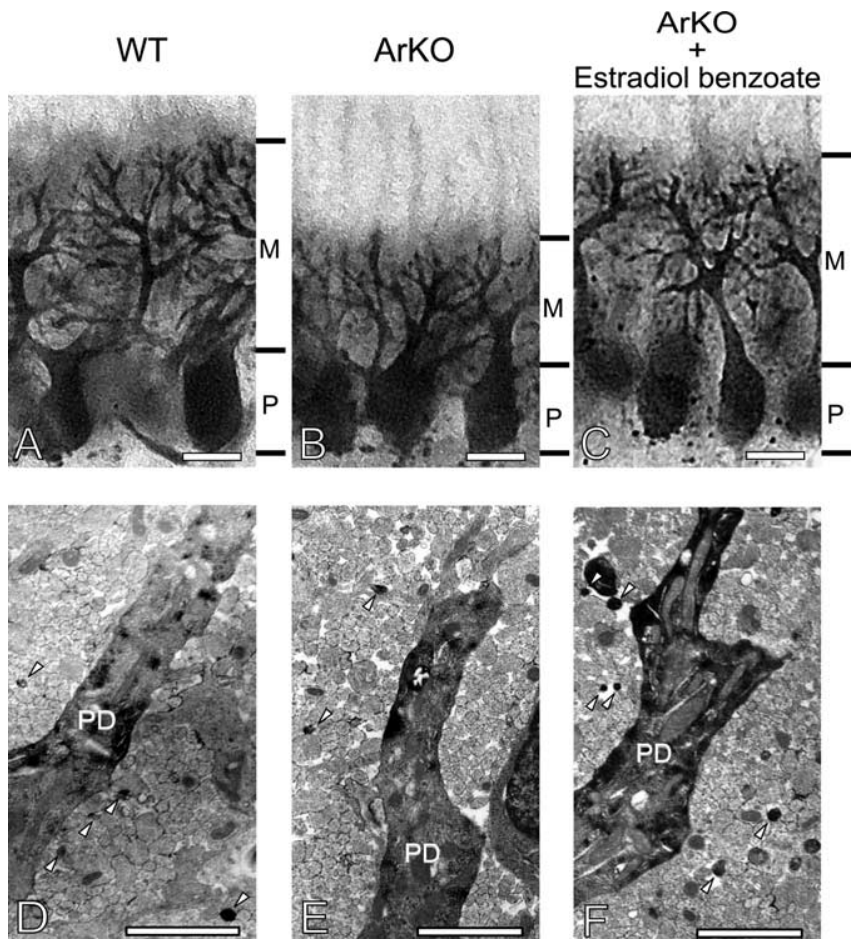

Figure 4. $\quad A-C$, Morphological analysis of Purkinje cell dendrites of WT $(A)$, $\operatorname{ArKO}(B)$, and EB-treated ArKO ( $C$; ArKO + Estradiol benzoate) newborn mice. Parasagittal sections of cerebella at $6 \mathrm{~d}$ of age were immunostained for calbindin (lobe IX). Scale bars, $10 \mu \mathrm{m}$. M, Molecular layer; $P$, Purkinje cell layer. $\boldsymbol{D}-\boldsymbol{F}$, Ultrastructural analysis of dendritic spines of Purkinje cells of WT $(\boldsymbol{D})$, ArKO (E), and EB-treated ArKO $(\boldsymbol{F})$ newborn mice. Parasagittal sections of cerebella at $6 \mathrm{~d}$ of age were immunostained for calbindin (lobe IX). Arrowheads indicate presumptive spine structures. Scale bars, $2 \mu \mathrm{m}$. PD, Purkinje cell dendrite.
A

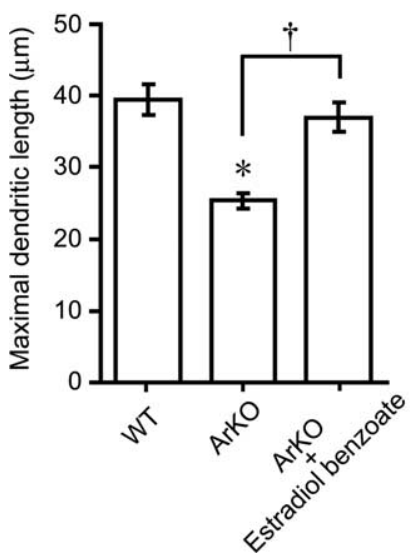

B

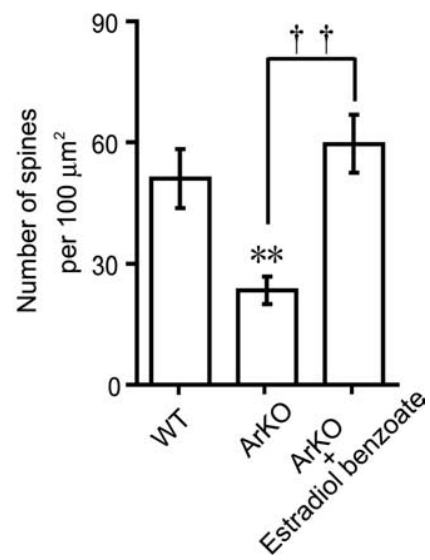

Figure 5. A, Quantitative analysis of the maximal Purkinje dendritic length of WT, ArK0, and EB-treated ArKO (ArKO + Estradiol benzoate) newborn mice. Each column and error bar represent the mean $\pm \operatorname{SEM}\left(n=5\right.$ in each group). ${ }^{*} p<0.05$ versus WT; ${ }^{\dagger} p<0.05$ ArKO versus ArKO plus EB (by one-way ANOVA, followed by Duncan's multiple range test). $B$, Quantitative electron microscopic analysis of Purkinje dendritic spine density per unit area (100 $\mu \mathrm{m}^{2}$ field) of WT, ArKO, and EB-treated ArKO newborn mice. Each column and error bar represent the mean \pm SEM ( $n=5$ in each group). ${ }^{* *} p<0.01$ versus WT; ${ }^{{ }^{\dagger}} p<0.01$ ArKO versus ArKO plus EB (by one-way ANOVA, followed by Duncan's multiple range test).

dritic spines on Purkinje cells (Fig. $4 E$ ) compared with the WT group (Fig. 4D). Quantitative electron microscopic analysis also showed a significant decrease in the density of dendritic spines on Purkinje cells (100 $\mu \mathrm{m}^{2}$ field) in ArKO mice compared with WT 
Table 3. Comparison of Purkinje cell number among WT, ArKO, and EB-treated ArKO (ArKO + EB) newborn mice

\begin{tabular}{lll}
\hline Group & Number of mice & Number of cells per mm lobe IX \\
\hline WT & 5 & $38.4 \pm 2.4$ \\
ArKO & 5 & $42.6 \pm 5.6$ \\
ArKO + EB & 5 & $36.9 \pm 1.0$ \\
\hline
\end{tabular}

There was no significant difference in the Purkinje cell number among different groups.
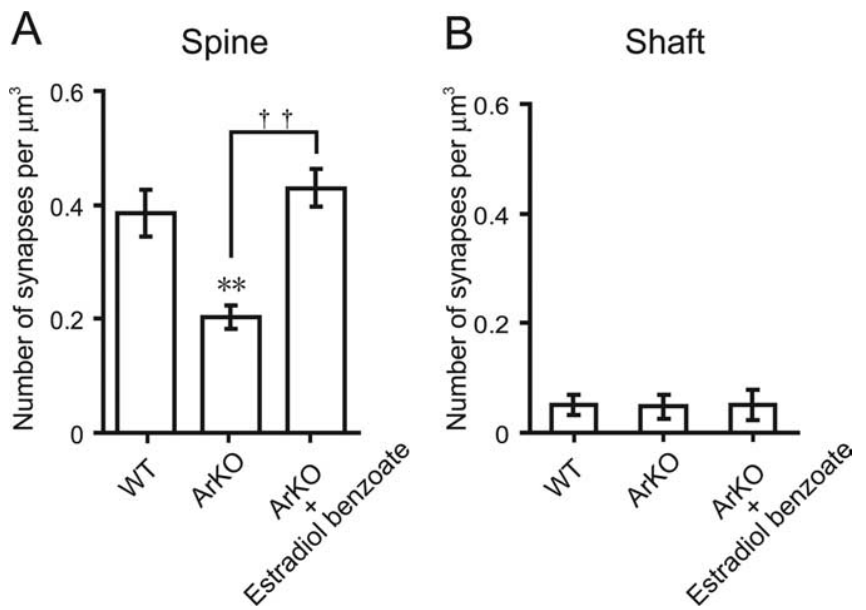

Figure 6. Quantitative electron microscopic analysis of Purkinje dendritic synapse density of WT, ArKO, and EB-treated ArKO (ArKO + Estradiol benzoate) newborn mice. A, Axospinous synapse density. $\boldsymbol{B}$, Shaft synapse density. Ultrathin sections (60 $\mathrm{nm}$ in thickness) containing calbindin-immunoreactive Purkinje dendrites in lobe IX at $6 \mathrm{~d}$ of age were analyzed. Each column and error bar represent the mean $\pm \operatorname{SEM}\left(n=5\right.$ in each group). ${ }^{* *} p<0.01$ versus WT; ${ }^{{ }^{+}} p<0.01$ ArKO versus ArKO plus EB (by one-way ANOVA, followed by Duncan's multiple range test).

mice $(p<0.01)$ (Fig. 5B). Administration of EB $(2 \mu \mathrm{g} / \mathrm{d})$ to ArKO mice significantly increased the density of Purkinje dendritic spines (100 $\mu \mathrm{m}^{2}$ field) $(p<0.01$ vs ArKO group), which reached the level of WT mice (Figs. $4 D-F, 5 B$ ).

Furthermore, quantitative electron microscopic analysis using an unfolding method revealed that the density of axospinous synapses on Purkinje cells in ArKO mice was significantly lower $(p<0.01)$ than that in WT mice (Fig. 6A). ArKO mice showed a $46 \%$ decrease in the density of synapses on Purkinje dendritic spines compared with WT mice (Fig. 6A). Administration of EB $(2 \mu \mathrm{g} / \mathrm{d})$ to ArKO mice significantly increased the density of axospinous synapses on Purkinje cells ( $p<0.01$ vs ArKO group), which reached the level of WT mice (Fig. 6A). However, there was no significant difference in the density of synapses located on Purkinje dendritic shafts among the groups of WT, ArKO, and EB-treated ArKO mice (Fig. 6B).

\section{Estrogen induces the expression of BDNF in mouse cerebella during development}

To elucidate the mode of action of estradiol, we further examined the expression of BDNF and NT-3 in the neonatal cerebellum after estrogen manipulation, because BDNF and NT-3 are known to be involved in Purkinje cell development (Rocamora et al., 1993; Ernfors et al., 1994; Neveu and Arenas, 1996; Schwartz et al., 1997; Bates et al., 1999).

The protein levels of BDNF and NT-3 in the neonatal cerebellum at $6 \mathrm{~d}$ of age were analyzed after the treatments with EB, tamoxifen, and EB plus tamoxifen ( $n=8$ in each group). Treatment with EB alone $(2 \mu \mathrm{g} / \mathrm{d})$ induced a significant increase in the level of BDNF in the cerebellum $(p<0.05$ vs vehicle-treated
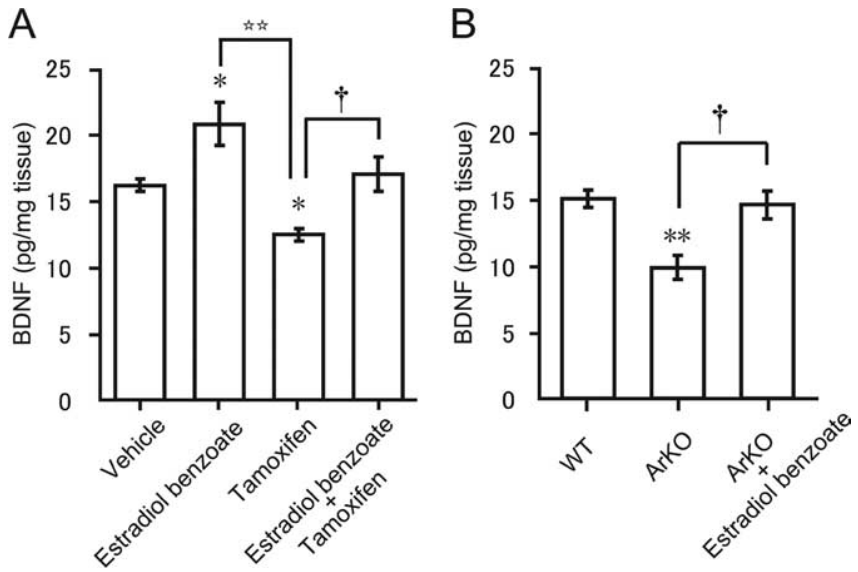

Figure 7. Changes in the level of BDNF in the neonatal cerebellum after estrogen manipulation. $A$, Comparison of the level of BDNF in newborn WT mice treated with vehicle, $E B$, tamoxifen, or EB plus tamoxifen. Each column and error bar represent the mean $\pm \operatorname{SEM}(n=8$ in each group). ${ }^{*} p<0.05$ versus vehicle; ${ }^{\dagger} p<0.05$ tamoxifen versus EB plus tamoxifen; $p<0.01$ EB versus tamoxifen (by one-way ANOVA, followed by Duncan's multiple range test). $\boldsymbol{B}, \mathrm{Com}-$ parison of the level of BDNF in WT, ArKO, and EB-treated ArKO (ArKO + Estradiol benzoate) newborn mice. Each column and error bar represent the mean $\pm \mathrm{SEM}$ ( $n=8$ in each group). ${ }^{* *} p<0.01$ versus WT; ${ }^{\dagger} p<0.05$ ArKO versus EB-treated ArKO (by one-way ANOVA, followed by Duncan's multiple range test).
A

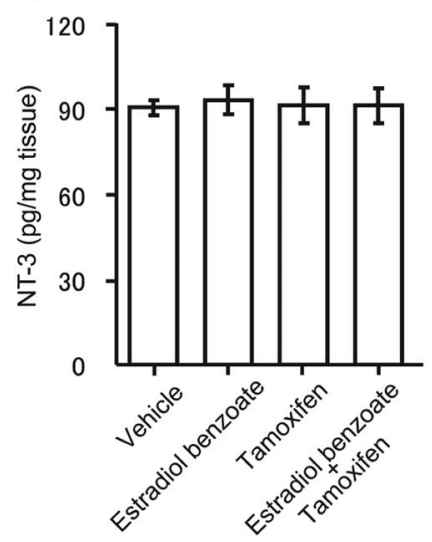

B

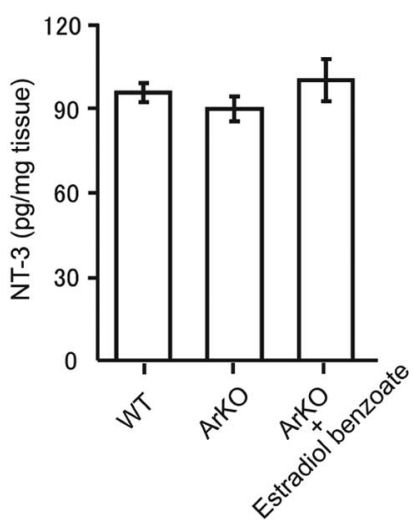

Figure 8. Changes in the level of NT-3 in the neonatal cerebellum after estrogen manipulation. $\boldsymbol{A}$, Comparison of the level of NT-3 in newborn WT mice treated with vehicle, EB, tamoxifen, or EB plus tamoxifen. Each column and error bar represent the mean $\pm \operatorname{SEM}(n=8$ in each group). $\boldsymbol{B}$, Comparison of the level of NT-3 in WT, ArKO, and EB-treated ArKO (ArKO + Estradiol benzoate) newborn mice. Each column and error bar represent the mean \pm SEM ( $n=8$ in each group).

group) (Fig. 7A), whereas tamoxifen alone $(200 \mu \mathrm{g} / \mathrm{d})$ significantly decreased the level of BDNF compared with the vehicletreated group $(p<0.05)$ (Fig. 7A). Combined treatments with EB $(2 \mu \mathrm{g} / \mathrm{d})$ and tamoxifen $(200 \mu \mathrm{g} / \mathrm{d})$ tended to abolish the estrogen-induced BDNF expression (Fig. 7A). In contrast, there was no significant difference in the level of NT-3 among the four groups (Fig. $8 \mathrm{~A}$ ).

The protein levels of BDNF and NT-3 in the neonatal cerebellum at $6 \mathrm{~d}$ of age were further compared among the groups of WT, ArKO, and EB-treated ArKO mice ( $n=8$ in each group) (Figs. $7 B, 8 B$ ). As shown in Figure $7 B$, ArKO mice significantly decreased $(p<0.01)$ the level of BDNF in the cerebellum compared with WT mice, and administration of EB $(2 \mu \mathrm{g} / \mathrm{d})$ to ArKO mice restored the level of BDNF to WT mice (Fig. $7 B$ ). In con- 

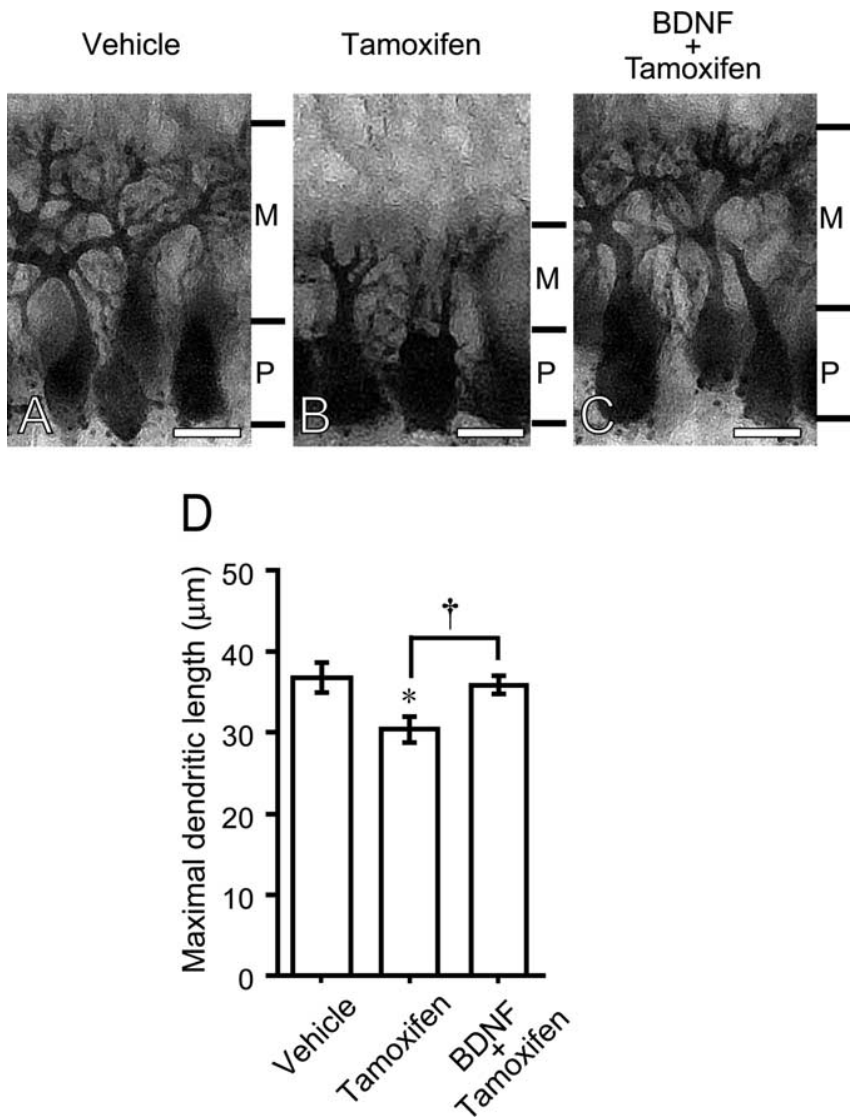

Figure 9. A-C, Morphological analysis of Purkinje cell dendrites of newborn WT mice treated with vehicle, tamoxifen, or BDNF plus tamoxifen. Parasagittal sections of cerebella at $6 \mathrm{~d}$ of age were immunostained for calbindin (lobe IX). Scale bars, $10 \mu \mathrm{m}$. M, Molecular layer; $\mathrm{P}$, Purkinje cell layer. $D$, Quantitative analysis of the maximal Purkinje dendritic length of newborn WT mice treated with vehicle, tamoxifen, or BDNF plus tamoxifen. Each column and error bar represent the mean \pm SEM ( $n=10$ in each group). ${ }^{*} p<0.05$ versus vehicle; ${ }^{\dagger} p<0.05$ tamoxifen versus BDNF plus tamoxifen (by one-way ANOVA, followed by Duncan's multiple range test).

trast, the level of NT-3 in the cerebellum did not change among the three groups (Fig. $8 B$ ).

\section{BDNF promotes dendritic growth of mouse Purkinje cells during development}

To investigate the effect of BDNF on Purkinje cell morphology, local administration of BDNF to tamoxifen-treated newborn WT mice was conducted. In this experiment, the length of molecular layer was also analyzed as a parameter of the maximal Purkinje dendritic length at $6 \mathrm{~d}$ of age after in vivo treatments with tamoxifen, and BDNF plus tamoxifen ( $n=10$ in each group) after immunostaining for calbindin (Fig. 9A-C). Treatment with tamoxifen alone $(200 \mu \mathrm{g} / \mathrm{d})$ decreased significantly $(p<0.05)$ the maximal Purkinje dendritic length compared with the vehicletreated group (Fig. $9 A, B, D$ ). In contrast, combined treatments with BDNF (150 pg/d) and tamoxifen at a concentration of 200 $\mu \mathrm{g} / \mathrm{d}$ restored the maximal Purkinje dendritic length (Fig. 9A$D$ ), suggesting that BDNF mediates estrogen action on Purkinje dendritic growth.

\section{Discussion}

The Purkinje cell is a major site for the formation of neurosteroids including estradiol in rats and other vertebrates (Usui et al., 1995; Ukena et al., 1998, 1999; Takase et al., 1999; Matsunaga et al., 2001; Sakamoto et al., 2001b, 2003a; Matsunaga et al., 2004). We found previously that estradiol promotes dendritic growth of Purkinje cells in newborn rats (Sakamoto et al., 2003a) and show now that this result generalizes to newborn mice. To demonstrate whether estradiol is involved in cerebellar neuronal circuit formation, this present study analyzed Purkinje dendritic spinogenesis and synaptogenesis in response to estrogen using normal WT and ArKO mice in the neonate. In vivo administration of EB, a stable form of estradiol, to newborn WT mice increased the densities of Purkinje dendritic spines and axospinous synapses electron microscopically. In contrast, the ER antagonist tamoxifen decreased the densities of Purkinje dendritic spines and axospinous synapses. These results suggest that estradiol is involved in cerebellar neuronal circuit formation during neonatal life by promoting not only the dendritic growth of Purkinje cells but also the formation of Purkinje dendritic spines and axospinous synapses. In this study, the number of synapses on the possible spine structures in the superficial molecular layer of the cerebellar cortex was counted electron microscopically, because it was technically difficult to count the number of synapses on the proximal primary dendrite of Purkinje cells. Therefore, most synapses counted in this study are considered to exist on the distal dendrite of Purkinje cells. The observation by estradiol administration to newborn WT mice was confirmed by the present study with ArKO mice. Estradiol deficiency in ArKO mice decreased dendritic growth, spinogenesis, and synaptogenesis in Purkinje cells in the neonate. In addition, administration of estradiol to ArKO mice increased Purkinje dendritic growth, spinogenesis, and synaptogenesis. These findings suggest physiological actions of endogenous estrogen on the promotion of dendritic growth, spinogenesis, and synaptogenesis in the developing Purkinje cell. Future study is needed to demonstrate whether these estrogen effects are permanent or transient.

Postnatal development in the cerebellum is dramatic during neonatal life (Altman, 1972a,b), when cerebellar estradiol is high under normal physiological conditions (Sakamoto et al., 2003a). Therefore, a high level of cerebellar estradiol during neonatal life may be essential for the formation of the cerebellar neuronal circuit that occurs during neonatal life. Sakamoto et al. (2003a) also found that, in neonatal rats, the cerebellar estradiol concentration was maximal because of the increase of P450arom expression and much higher than that in the plasma. Therefore, it is possible that estrogen produced in Purkinje cells acts directly on Purkinje cells in neonatal mice. However, we cannot rule out the possibility that estradiol produced in the peripheral steroidogenic organs acts on Purkinje cells. Because external granule cells in the cerebellum also express $3 \beta$-HSD and P450arom (Ukena et al., 1999; Sakamoto et al., 2003a), we need precise biochemical analyses to investigate the local production and concentration of estradiol within Purkinje cells. Conversely, several investigators have shown that ovarian estradiol promotes spinogenesis and synaptogenesis in other brain regions, such as hippocampus (Gould et al., 1990; Woolley et al., 1990; Woolley and McEwen, 1992, 1994; Murphy and Segal, 1996; McEwen et al., 2001) and hypothalamus (Pérez et al., 1993; Langub et al., 1994).

It has been reported that the neonatal rat Purkinje cell expresses ER $\beta$ (Price and Handa, 2000; Jakab et al., 2001). Mitra et al. (2003) also detected $E R \beta$ immunoreactivity in the nuclei of pyramidal cells (most likely Purkinje cells) and granular cells and in fibers in the molecular layer of the mouse cerebellum. Consequently, estradiol may act directly on the Purkinje cell through ER $\beta$-mediated mechanisms, to promote the dendritic growth, spinogenesis, and synaptogenesis in Purkinje cells. This hypoth- 
esis is supported by the present finding with the ER antagonist tamoxifen, which inhibited the effects of estrogen on Purkinje dendritic growth, spinogenesis, and synaptogenesis. It is known that this antiestrogen binds to $\mathrm{ERs}(\mathrm{ER} \alpha$ and $\mathrm{ER} \beta)$ and activates transcription via activating protein-1 response elements (Webb et al., 1995) but blocks transcriptional activation through the classical estrogen response element and not producing any agonist effect via this pathway (McDonnell et al., 1995; Paech et al., 1997). Thus, it is considered that the antiestrogen tamoxifen used in this study blocks transcriptional activation of $\operatorname{ER} \beta$ in the developing Purkinje cell. Conversely, estradiol might also act on Purkinje cells via non-nuclear ERs. According to Smith et al. (1988) and Smith (1989), locally applied estrogens and antiestrogens can alter glutamate-evoked excitation of Purkinje cells. It has also been reported that the effect of estradiol on hippocampal CA1 pyramidal cell dendrite spine density requires the activation of NMDA receptors in adult female rats (Woolley and McEwen, 1994). Such nongenomic estrogen actions may lead to alterations in gene expression. Recent ultrastructural studies have revealed extranuclear ER $\alpha$ immunoreactivity within select dendritic spines on hippocampal principal cells, axon terminals, and glial processes (McEwen et al., 2001), suggesting nongenomic action of estrogen via $\mathrm{ER} \alpha$ in this brain region.

Because it has been reported that neurotrophic factors, such as BDNF and NT-3, are highly expressed in the developing cerebellum (Rocamora et al., 1993; Ernfors et al., 1994; Neveu and Arenas, 1996; Schwartz et al., 1997; Bates et al., 1999), estradiol may induce the expression of some neurotrophic factors. Administration of estrogen to newborn WT mice increased the level of BDNF in the cerebellum. ArKO mice decreased the level of BDNF in the cerebellum compared with WT mice. Estrogen administration to ArKO mice restored the level of BDNF to WT mice. In addition, BDNF administration to tamoxifen-treated WT mice increased Purkinje dendritic growth. In contrast to BDNF, estrogen administration did not influence the level of NT-3 in the cerebellum. The NT-3 level also did not change in ArKO mice. These results suggest that BDNF mediates estrogen action on the promotion of dendritic growth, spinogenesis, and synaptogenesis in the developing Purkinje cell. In fact, the gene encoding BDNF contains a sequence similar to the canonical estrogen response element found in estrogen-target genes (Sohrabji et al., 1995). In addition, BDNF increases levels of synaptic vesicle proteins, such as synaptophysin and synapsin 1, which are reliable markers of synaptogenesis, in the spinal neurons (Wang et al., 1995). Estrogen increases presynaptic and postsynaptic proteins, such as syntaxin, synaptophysin, and spinophilin, in the CA1 region of the primate hippocampus (Choi et al., 2003). Furthermore, it has been reported that EB treatment induces these synaptic proteins in the CA1 region of hippocampus, and this effect is blocked by CI628 [ $\alpha$-(4-pyrrolidinethoxyl)phenyl-4-methoxy$\alpha$-nitrostilbene], an antiestrogen of the tamoxifen type (Brake et al., 2001). The expression of P450arom mRNA in the cerebellum is restricted to Purkinje cells and external granule cells in the neonatal rats (Sakamoto et al., 2003a; Tsutsui, 2006; Tsutsui and Mellon, 2006). Both Purkinje cells and granule cells express BDNF (Hofer et al., 1990; Borghesani et al., 2002) and TrkB, a receptor for BDNF (Klein et al., 1990; Segal et al., 1995; Carter et al., 2002). It is therefore possible that estrogen induces the expression of BDNF, which acts on Purkinje cells and granule cells through TrkB-mediated mechanisms to promote Purkinje dendritic growth, spinogenesis, and synaptogenesis. Because it has been demonstrated that, in the vermal lobe, Purkinje cells and granule cells require BDNF for normal cortical development (Schwartz et al., 1997), we analyzed the vermal lobe of the cerebellum in this study. Therefore, we cannot state whether the development of vermal lobe is the same as the other part of the cerebellum, i.e., hemisphere.

It is well established that ArKO mice are a new animal model for the study for estrogen actions. As regarding brain functions of ArKO mice, abnormalities of sexual motivation and performance, aggressive behavior, parental behavior, and exploring or anxiety behavior have been reported (Honda et al., 1998; Bakker et al., 2002a,b; Aste et al., 2003; Matsumoto et al., 2003). These abnormalities were restored by estradiol treatment or introduction of P450arom gene with a brain-specific promoter and exon If into ArKO mice (S. Honda and N. Harada, unpublished observation). Neuroprotective and neurotrophic actions of estrogen have been reported by the studies using ArKO mice (Azcoitia et al., 1999; Carswell et al., 2005). Neuroprotective effects of estrogen on dentate gyrus neurons in the hippocampus were mediated by estrogen-induced IGF-1 (Azcoitia et al., 1999), similar to neurotrophic effects of estrogen on Purkinje cells mediated by estrogen-induced BDNF. In this study, ArKO mice decreased Purkinje dendritic growth, spinogenesis, and synaptogenesis compared with WT mice. The deficiency of endogenous estrogen in ArKO mice used in this study has also been confirmed (Honda et al., 1998; Matsumoto et al., 2003). It is therefore considered that endogenous estrogen functions in the Purkinje cell during neonatal life. However, we cannot rule out another possibility, that a high level of endogenous testosterone in ArKO mice (Fisher et al., 1998) might reduce Purkinje dendritic growth, spinogenesis, and synaptogenesis observed in this study.

In conclusion, estradiol promotes Purkinje dendritic growth, spinogenesis, and synaptogenesis during neonatal life by inducing the expression of BDNF. These estrogen actions may be essential for cerebellar neuronal circuit formation.

\section{References}

Altman J (1972a) Postnatal development of the cerebellar cortex in the rat. I. The external germinal layer and the transitional molecular layer. J Comp Neurol 145:353-398.

Altman J (1972b) Postnatal development of the cerebellar cortex in the rat. II. Phases in the maturation of Purkinje cells and of the molecular layer. J Comp Neurol 145:399-464.

Aste N, Honda S, Harada N (2003) Forebrain Fos responses to reproductively related chemosensory cues in aromatase knockout mice. Brain Res Bull 60:191-200.

Azcoitia I, Sierra A, Veiga S, Honda S, Harada N, Garcia-Segura LM (1999) Brain aromatase is neuroprotective. J Neurosci Res 58:815-822.

Bakker J, Honda S, Harada N, Balthazart J (2002a) The aromatase knockout mouse provides new evidence that estradiol is required during development in the female for the expression of sociosexual behaviors in adulthood. J Neurosci 22:9104-9112.

Bakker J, Honda S, Harada N, Balthazart J (2002b) Sexual partner preference requires a functional aromatase (cyp19) gene in male mice. Horm Behav 42:158-171.

Bates B, Rios M, Trumpp A, Chen C, Fan G, Bishop JM, Jaenisch R (1999) Neurotrophin-3 is required for proper cerebellar development. Nat Neurosci 2:115-117.

Baulieu EE (1997) Neurosteroids: of the nervous system, by the nervous system, for the nervous system. Recent Prog Horm Res 52:1-32.

Bliss CI (1952) The statistics of bioassay. New York: Academic.

Borghesani PR, Peyrin JM, Klein R, Rubin J, Carter AR, Schwartz PM, Luster A, Corfas G, Segal RA (2002) BDNF stimulates migration of cerebellar granule cells. Development 129:1435-1442.

Brake WG, Alves SE, Dunlop JC, Lee SJ, Bulloch K, Allen PB, Greengard P, McEwen BS (2001) Novel target sites for estrogen action in the dorsal 
hippocampus: an examination of synaptic proteins. Endocrinology 142:1284-1289.

Bravin M, Morando L, Vercelli A, Rossi F, Strata P (1999) Control of spine formation by electrical activity in the adult rat cerebellum. Proc Natl Acad Sci USA 96:1704-1709.

Carswell HVO, Dominiczak AF, Garcia-Segura LM, Harada N, Hutchison JB, Macrae IM (2005) Brain aromatase expression after experimental stroke: topography and time course. J Steroid Biochem Mol Biol 96:89-91.

Carter AR, Chen C, Schwartz PM, Segal RA (2002) Brain-derived neurotrophic factor modulates cerebellar plasticity and synaptic ultrastructure. J Neurosci 22:1316-1327.

Choi JM, Romeo RD, Brake WG, Bethea CL, Rosenwaks Z, McEwen BS (2003) Estradiol increases pre- and post-synaptic proteins in the CA1 region of the hippocampus in female rhesus macaques (Macaca mulatta). Endocrinology 144:4734-4738.

Compagnone NA, Mellon SH (2000) Neurosteroids: biosynthesis and function of these novel neuromodulators. Front Neuroendocrinol 21:1-56.

Cruz-Orive LM (1983) Distribution-free estimation of sphere size distributions from slabs showing overprojection and truncation, with a review of previous methods. J Microsc 131:265-290.

Ernfors P, Lee KF, Jaenisch R (1994) Mice lacking brain-derived neurotrophic factor develop with sensory deficits. Nature 368:147-150.

Fisher CR, Graves KH, Parlow AF, Simpson ER (1998) Characterization of mice deficient in aromatase (ArKO) because of targeted disruption of the cyp19 gene. Proc Natl Acad Sci USA 95:6965-6970.

Givalois L, Naert G, Rage F, Ixart G, Arancibia S, Tapia-Arancibia L (2004) A single brain-derived neurotrophic factor injection modifies hypothalamo-pituitary-adrenocortical axis activity in adult male rats. Mol Cell Neurosci 27:280-295.

Gould E, Woolley CS, Frankfurt M, McEwen BS (1990) Gonadal steroids regulate dendritic spine density in hippocampal pyramidal cells in adulthood. J Neurosci 10:1286-1291.

Hofer M, Pagliusi SR, Hohn A, Leibrock J, Barde YA (1990) Regional distribution of brain-derived neurotrophic factor mRNA in the adult mouse brain. EMBO J 9:2459-2464.

Honda S, Harada N, Ito S, Takagi Y, Maeda S (1998) Disruption of sexual behavior in male aromatase-deficient mice lacking exons 1 and 2 of the cyp19 gene. Biochem Biophys Res Commun 252:445-449.

Jakab RL, Wong JK, Belcher SM (2001) Estrogen receptor $\beta$ immunoreactivity in differentiating cells of the developing rat cerebellum. J Comp Neurol 430:396-409.

Klein R, Parada LF, Coulier F, Barbacid M (1990) TrkB, a novel tyrosine protein kinase receptor expressed during mouse neural development. EMBO J 8:3701-3709.

Langub MC, Maley BE, Watson RE (1994) Estrous cycle-associated axosomatic synaptic plasticity upon estrogen receptive neurons in the rat preoptic area. Brain Res 641:303-310.

Matsumoto T, Honda S, Harada N (2003) Neurological effects of aromatase deficiency in the mouse. J Steroid Biochem Mol Biol 86:357-365.

Matsunaga M, Ukena K, Tsutsui K (2001) Expression and localization of cytochrome P450 17 $\alpha$-hydroxylase/c17, 20-lyase in the avian brain. Brain Res 899:112-122.

Matsunaga M, Ukena K, Baulieu EE, Tsutsui K (2004) $7 \alpha-$ Hydroxypregnenolone acts as a neuronal activator to stimulate locomotor activity of breeding newts by means of the dopaminergic system. Proc Natl Acad Sci USA 101:17282-17287.

McDonnell DP, Clemm DL, Hermann T, Goldman ME, Pike JW (1995) Analysis of estrogen receptor function in vitro reveals three distinct classes of antiestrogens. Mol Endocrinol 9:659-669.

McEwen B, Akama K, Alves S, Brake WG, Bulloch K, Lee S, Li C, Yuen G, Milner TA (2001) Tracking the estrogen receptor in neurons: implications for estrogen-induced synapse formation. Proc Natl Acad Sci USA 98:7093-7100.

Mitra SW, Hoskin E, Yudkovitz J, Pear L, Wilkinson HA, Hayashi S, Pfaff DW, Ogawa S, Rohrer SP, Schaeffer JM, McEwen BS, Alves SE (2003) Immunolocalization of estrogen receptor $\beta$ in the mouse brain: comparison with estrogen receptor $\alpha$. Endocrinology 144: 2055-2067.

Murphy DD, Segal M (1996) Regulation of dendritic spine density in cul- tured rat hippocampal neurons by steroid hormones. J Neurosci 16:4059-4068.

Neveu I, Arenas E (1996) Neurotrophins promote the survival and development of neurons in the cerebellum of hypothyroid rats in vivo. J Cell Biol 133:631-646.

Paech K, Webb P, Kuiper GGJM, Nilsson S, Gustafsson J-Å, Kushner PJ, Scanlan TS (1997) Differential ligand activation of estrogen receptors ER $\alpha$ and ER $\beta$ at AP1 sites. Science 277:1508-1510.

Pérez J, Luquín S, Naftolin F, García-Segura LM (1993) The role of estradiol and progesterone in phased synaptic remodelling of the rat arcuate nucleus. Brain Res 608:38-44.

Pollock GS, Vernon E, Forbes ME, Yan Q, Ma YT, Hsieh T, Robichon R, Frost DO, Johnson JE (2001) Effects of early visual experience and diurnal rhythms on BDNF mRNA and protein levels in the visual system, hippocampus, and cerebellum. J Neurosci 21:3923-3931.

Price RH, Handa RJ (2000) Expression of estrogen receptor- $\beta$ protein and mRNA in the cerebellum of the rat. Neurosci Lett 288:115-118.

Rocamora N, Garcia-Ladona FJ, Palacios JM, Mengod G (1993) Differential expression of brain-derived neurotrophic factor, neurotrophin-3, and low-affinity nerve growth factor receptor during the postnatal development of the rat cerebellar system. Brain Res Mol Brain Res 17:1-8.

Sakamoto H, Ubuka T, Kohchi C, Li D, Ukena K, Tsutsui K (2000) Existence of galanin in lumbosacral sympathetic ganglionic neurons that project to the quail uterine oviduct. Endocrinology 141:4402-4412.

Sakamoto H, Ukena K, Tsutsui K (2001a) Effects of progesterone synthesized de novo in the developing Purkinje cell on its dendritic growth and synaptogenesis. J Neurosci 21:6221-6232.

Sakamoto H, Ukena K, Tsutsui K (2001b) Activity and localization of $3 \beta$ hydroxysteroid dehydrogenase $/ \Delta^{5}-\Delta^{4}$-isomerase in the zebrafish central nervous system. J Comp Neurol 439:291-305.

Sakamoto H, Ukena K, Tsutsui K (2002) Dendritic spine formation in response to progesterone synthesized de novo in the developing Purkinje cell in rats. Neurosci Lett 322:111-115.

Sakamoto H, Mezaki Y, Shikimi H, Ukena K, Tsutsui K (2003a) Dendritic growth and spine formation in response to estrogen in the developing Purkinje cell. Endocrinology 144:4466-4477.

Sakamoto H, Shikimi H, Ukena K, Tsutsui K (2003b) Neonatal expression of progesterone receptor isoforms in the cerebellar Purkinje cell in rats. Neurosci Lett 343:163-166.

Schwartz PM, Borghesani PR, Levy RL, Pomeroy SL, Segal RA (1997) Abnormal cerebellar development and foliation in BDNF-/- mice reveals a role for neurotrophins in CNS patterning. Neuron 19:269-281.

Segal RA, Pomeroy SL, Stiles CD (1995) Axonal growth and fasciculation linked to differential expression of BDNF and NT3 receptors in developing cerebellar granule cells. J Neurosci 15:4970-4981.

Smith SS (1989) Estrogen administration increases neuronal responses to excitatory amino acids as a long-term effect. Brain Res 503:354-357.

Smith SS, Waterhouse BD, Woodward DJ (1988) Locally applied estrogens potentiate glutamate-evoked excitation of cerebellar Purkinje cells. Brain Res 475:272-282.

Sohrabji F, Miranda RC, Toran-Allerand CD (1995) Identification of a putative estrogen response element in the gene encoding brain-derived neurotrophic factor. Proc Natl Acad Sci USA 92:11110-11114.

Takase M, Ukena K, Yamazaki T, Kominami S, Tsutsui K (1999) Pregnenolone, pregnenolone sulfate and cytochrome P450 side-chain cleavage enzyme in the amphibian brain and their seasonal changes. Endocrinology 140:1936-1944.

Tsutsui K (2006) Biosynthesis and organizing action of neurosteroids in the developing Purkinje cell. Cerebellum 5:89-96.

Tsutsui K, Mellon SH (2006) Neurosteroids in the brain neuron: biosynthesis, action and medicinal impact on neurodegenerative disease. Central Nerv Syst Agents Med Chem 6:73-82.

Tsutsui K, Ukena K, Usui M, Sakamoto H, Takase M (2000) Novel brain function: biosynthesis and actions of neurosteroids in neurons. Neurosci Res 36:261-273.

Tsutsui K, Sakamoto H, Ukena K (2003a) A novel aspect of the cerebellum: biosynthesis of neurosteroids in the Purkinje cell. Cerebellum 2:215-222.

Tsutsui K, Sakamoto H, Ukena K (2003b) Biosynthesis and action of neuro- 
steroids in the cerebellar Purkinje neuron. J Steroid Biochem Mol Biol 85:311-321.

Ukena K, Usui M, Kohchi C, Tsutsui K (1998) Cytochrome P450 side-chain cleavage enzyme in the cerebellar Purkinje neuron and its neonatal change in rats. Endocrinology 139:137-147.

Ukena K, Kohchi C, Tsutsui K (1999) Expression and activity of $3 \beta$ hydroxysteroid dehydrogenase $/ \Delta^{5}-\Delta^{4}$-isomerase in the rat Purkinje neuron during neonatal life. Endocrinology 140:805-813.

Usui M, Yamazaki T, Kominami S, Tsutsui K (1995) Avian neurosteroids. II. Localization of a cytochrome P450scc-like substance in the quail brain. Brain Res 678:10-20.

Wang T, Xie K, Lu B (1995) Neurotrophins promote maturation of developing neuromuscular synapses. J Neurosci 15:4796-4805.
Webb P, Lopez GN, Uht RM, Kushner PJ (1995) Tamoxifen activation of the estrogen receptor/AP-1 pathway: potential origin for the cellspecific estrogen-like effects of antiestrogens. Mol Endocrinol 9:443-456.

Woolley CS, McEwen BS (1992) Estradiol mediates fluctuation in hippocampal synapse density during the estrous cycle in the adult rat. J Neurosci 12:2549-2554.

Woolley CS, McEwen BS (1994) Estradiol regulates hippocampal dendritic spine density via an $\mathrm{N}$-methyl-D-aspartate receptor-dependent mechanism. J Neurosci 14:7680-7687.

Woolley CS, Gould E, Frankfurt M, McEwen BS (1990) Naturally occurring fluctuation in dendritic spine density on adult hippocampal pyramidal neurons. J Neurosci 10:4035-4039. 